\title{
Effect of Quetiapine in young schizophrenic patients with tardive dyskinesia
}

\author{
Piyush Singh*, Abu Qamar Siddiqui, Rakesh Gaur \\ From $1^{\text {st }}$ International Congress on Neurobiology and Clinical Psychopharmacology and European \\ Psychiatric Association Conference on Treatment Guidance \\ Thessaloniki, Greece. 19-22 November 2009
}

\section{Background}

One of the major challenges in long term psychopharmacological management of schizophrenia is development of side effects, most notably tardive dyskinesia. The problem of tardive dyskinesia (TD) was more prevalent with the use of first - generation anti psychotic medications; the second generation drugs are believed to have a lesser propensity to cause such movement disorder. However, once TD develops the treatment options are rather limited, with the possible exception of Clozapine - usually modestly effective in about half of the patients. Thus there exists a need for searching alternative therapeutic methods for tackling this vexing problem.

\section{Aim}

The aim was to find out if use of quetiapine is associated with a decrease in tardive dyskinesia, in young patients of schizophrenia who developed TD on their first anti psychotic medication.

\section{Materials and methods}

This was an open label observation study involving six male patients diagnosed as suffering from acute schizophrenia for which they had been prescribed anti psychotic medications, namely haloperidol and Risperidone. The patients went on to develop tardive dyskinesias. The dyskinetic movements were predominantly involving facial and oral areas. The dyskinetic movements were rated with Abnormal Involuntary Movements Scale. Attempts to decrease or withdraw the drugs resulted in re-emergence of symptoms. A trial of quetiapine was carried out with a cross over and taper method of 2-3 weeks. The AIMS ratings were carried out at 0 ,
4 and 8 week intervals. A reduction in the scores on AIMS was observed.

\section{Results}

It was observed that young male patients $(<30 \mathrm{yrs}$. $)$ who had received either haloperidol (5- $12.5 \mathrm{mgs}$./day) or Risperidone (4- $8 \mathrm{mgs}$./day) in oral formulations as their first anti psychotic medication. They had these drugs for 4- 9 month duration. All of them also had received oral trihexyphenidyl (2-6 mgs./day) concomitantly, but still developed involuntary movements. Their personal, family and medical history and physical examination, including neurological examination, were free of any neurological or movement disorder. They were not receiving any other concomitant medications. After cross-taper, quetiapine was used at 300- $600 \mathrm{mgs}$./day dose. AIMS ratings at 4 and 8 weeks after start of quetiapine therapy revealed a decrease in tongue, lips and perioral movements. Detailed ratings will be discussed at presentation.

\section{Conclusions}

Although Clozapine has been found to result in decrease of TD movements; its use is problematic due to side-effects and regular blood monitoring, which is very difficult in developing countries. Quetiapine, associated with least propensity for causing EPSEs, appears to be promising for decreasing TD. This case report supports the limited evidence base in support of the use of quetiapine for managing tardive dyskinesia, especially in a younger population who themselves have somewhat lesser propensity to develop TD.

Department of Psychiatry, JN Medical College, Aligarh, India 


\section{References}

1. Janicak PG, Davis JM, Preskorn SH, Ayd FJ Jr, Marder S: Principles and Practice of Psychopharmacotherapy., 42006.

2. Sadock BJ, Sadock VA, Ruiz P: Comprehensive Textbook of Psychiatry., 92009.

3. Soares-Weiser K, Fernandez HH: Tardive dyskinesia. Semin Neurol 2007, 27:159.

doi:10.1186/1744-859X-9-S1-S178

Cite this article as: Singh et al:: Effect of Quetiapine in young schizophrenic patients with tardive dyskinesia. Annals of General Psychiatry 2010 9(Suppl 1):S178.

Submit your next manuscript to BioMed Central and take full advantage of:

- Convenient online submission

- Thorough peer review

- No space constraints or color figure charges

- Immediate publication on acceptance

- Inclusion in PubMed, CAS, Scopus and Google Scholar

- Research which is freely available for redistribution

Submit your manuscript at www.biomedcentral.com/submit 